\section{Indra Tri Astuti;} Nopi Nur Khasanah ${ }^{1}$

1 Departemen IImu Keperawatan Anak Fakultas IImu Keperawatan Universitas Islam Sultan Agung, Semarang, Indonesia Email: ners.nopi@gmail.com

\title{
Uji Beda Efek Guided Imagery dan Ethyl Chloride Terhadap Nyeri Saat Pemasangan Infus pada Anak
}

\section{Info Artikel:}

Masuk : 24 Februari 2017

Revisi : 20 Mei 2017

Diterima : : 6 Juni 2017

DOI Number : 10.18196/ijnp.1263

\begin{abstract}
ABSTRAK
Pemasangan infus merupakan tindakan invasif awal yang seringkali dilakukan di Instalansi Gawat Darurat (IGD) guna memenuhi kebutuhan cairan dan elektrolit. Tindakan tersebut dapat menyebabkan nyeri pada anak. Nyeri yang tidak ditangani dapat mengakibatkan dampak yang serius, baik jangka pendek maupun jangka panjang. Perawat perlu menggunakan metode yang tepat untuk mengurangi nyeri pada anak saat pemasangan infus guna meminimalkan dampak tersebut. Tujuan penelitian ini untuk menganalisis perbedaan antara intervensi guided imagery dan ethyl chloride terhadap skor nyeri anak saat pemasangan infus.

Penelitian ini menggunakan desain penelitian semu (quasi experiment) dengan postest kelompok kontrol nonekuivalen (after only onequivalent control group design). Jumlah total responden 30 anak yang diambil dengan teknik consecutive sampling. Skor nyeri diukur dengan Wong-Baker face pain rating scale dan dianalisis secara statistik dengan uji post hoc Mannwhitney. Hasil menunjukkan nilai $\square$ sebesar $0,530(\square>0,05)$ artinya tidak terdapat perbedaan skor nyeri yang bermakna antara kedua intervensi. Hal ini menunjukkan bahwa Guided imagery dapat dijadikan alternatif penatalaksanaan nyeri non farmakologi dan non invasif pada anak saat pemasangan infus di IGD.

Kata kunci: Ethyl chloride, Guided imagery, Nyeri pada anak, Pemasangan infus
\end{abstract}

\section{ABSTRACT}

The infusion procedures are the first invasive treatment conducted in Emergency Room (ER) to fullfil the need of fluid and electrolyte. Those treatments can cause pain on children. The untreated pain can cause 


\section{NURSING PRACTICES}

any serious effect, both in short term and long term. Nurses need to use the appropriate method to decrease the pain on children when infusion is installed to decrease those effects. This study is aimed to analyze the differences of children pain score when having infusion procedures with guided imagery and ethyl chloride intervention. This study used quasi experimental study with 30 children as participants by using non equivalent control group design. The group was taken by using consecutive sampling technique. The data was collected by using Wong-Baker face pain rating scale and analyzed by post hoc Mann-Whitney test. The result showed that $\square$ value were $0,530(\square>0,05)$, of which can be concluded that there is no significant difference on the two interventions. Guided imagery could be used as an alternative pain management for non farmachology and non invasive on children when having the infusion procedures at ER.

Keywords: ethyl chloride, guided imagery, pain on children, infusion procedures.

\section{PENDAHULUAN}

Nyeri menurut International Association for Study of Pain (IASP, 1997 dalam Glasper dan Richardson, 2006), nyeri adalah sensori subyektif dan emosional yang tidak menyenangkan yang didapat terkait dengan kerusakan jaringan aktual maupun potensial, atau menggambarkan kondisi dimana terjadinya kerusakan. Nyeri dapat diartikan sebagai suatu perasaan tidak nyaman atau tidak menyenangkan yang sering dialami oleh individu (Andarmoyo, 2013). Nyeri pada anak yang tidak segera diatasi akan berdampak secara fisik maupun perilaku. Dampak fisik dari nyeri terbagi atas dampak akut (jangka pendek), yang ditandai dengan peningkatan laju metabolisme dan curah jantung, kerusakan respon insulin, peningkatan produksi kortisol, dan meningkatnya retensi cairan. Adapun dampak kronis (jangka panjang), dimana nyeri berlangsung terus-menerus dan dalam waktu yang lama, akan meningkatkan stres pada anak serta mengakibatkan ketidakmampuan melakukan aktifitas.

Anak yang harus mendapatkan perawatan di Rumah Sakit seringkali mendapatkan pengalaman dari berbagai prosedur invasif yang perlu dijalani. Pemasangan infus merupakan salah satu tindakan invasif awal yang menentukan keberhasilan prosedur tindakan selanjutnya. Apabila kesan pertama saat dilakukan prosedur tindakan anak merasa nyaman, untuk dilakukan tindakan selanjutnya akan lebih mudah, karena dalam presepsi anak tindakan sebelumnya tidak menyakitkan. Hal ini sebagaimana konsep atraumatic care yang seharusnya dilakukan perawat. Atraumatic care adalah ketentuan dalam konsep perawatan terapeutik, yang dilakukan perawat melalui tindakan menghilangkan atau meminimalkan tekanan psikologis dan fisik yang dialami oleh anak dan keluarga dalam sistem perawatan kesehatan (Hockenberry \& Wilson, 2009).

Berbagai penelitian kesehatan secara holistik guna mengatasi nyeri telah banyak dikembangkan, baik berupa terapi farmakologi maupun nonfarmakologi. Penelitian yang dilakukan oleh Mariyam dan Widodo (2012) mengenai pengaruh guided imagery terhadap tingkat nyeri anak saat dilakukan pemasangan infus, dengan hasil rata-rata tingkat nyeri pada kelompok yang dilakukan guided imagery lebih rendah dibanding kelompok kontrol. Penelitian lain dalam mengatasi nyeri diteliti oleh Ismanto (20 I I) mendapatkan hasil bahwa respon nyeri bayi saat imunisasi yang diukur dengan skala FLACC, terdapat perbedaan yang signifikan antara kelompok intervensi ASI dengan kelompok topikal anestesi (FluoriMethane) spray, yaitu rata-rata respon nyeri pada bayi yang diberi ASI lebih rendah dari bayi yang diberi intervensi dengan topikal anestesi spray saat dilakukan imunisasi.

Fenomena tersebut menarik peneliti untuk melakukan penelitian guna menemukan metode yang tepat dilakukan pada anak saat pemasangan infus. Metode yang dipilih oleh peneliti yaitu guided imagery, dengan menggunakan rekaman kaset imajinasi sehingga anak lupa terhadap nyeri yang dirasakan. Dengan pertimbangan guided imagery mudah dibuat rekaman sendiri, terjangkau, dan bisa dipakai sewaktu-waktu oleh anak. Adapun metode alternatif lain yang dipilih peneliti yaitu dengan anestesi topikal dengan jenis Ethyl chloride. Meski telah banyak penelitian tentang efektifitas krim EMLA untuk menurunkan nyeri, namun karena krim EMLA membutuhkan waktu cukup lama yaitu 30-60 menit, maka peneliti memilih Ethyl chloride jenis anestesi semprot dengan efek lebih cepat yaitu 15 detik saja. Penelitian oleh Siregar (2007) tentang perbedaan anestesi semprot dengan anestesi oles, mendapatkan hasil bahwa tidak ada perbedaan yang signifikan antara anestesi semprot dengan anestesi oles dalam menurunkan intensitas nyeri pada pungsi arteri. 
Fenomena yang tergambarkan di latar belakang menarik peneliti untuk bertanya "Apakah ada perbedaan skor nyeri pada anak usia 7-12 tahun saat pemasangan infus setelah diberikan intervensi ethyl chloride dan guided imagery?"

\section{METODE}

Penelitian ini merupakan penelitian kuantitatif, menggunakan desain penelitian eksperimen semu (quasi experiment) dengan pos-test treatment pada kelompok kontrol non-ekuivalen (after only nonequivalent control group design), dimana pada rancangan ini kelompok eksperimen maupun kontrol tidak dipilih secara random (Creswell, 20 I0). Rancangan ini menggunakan pos-tes pada kelompok kontrol maupun intervensi tanpa dilakukan pre-tes terlebih dahulu.

Intervensi dalam penelitian ini dilakukan dengan pemberian ethyl chloride pada kelompok intervensi I (kelompok kontrol) adapun pemberian guided imagery pada kelompok intervensi II (sebagai pembanding). Tindakan dilakukan 2 menit sebelum prosedur pemasangan infus. Pengukuran yang dilakukan sesudah intervensi meliputi skala nyeri pada menit kelima setelah dilakukan pemasangan infus.

Populasi dari penelitian ini adalah anak usia 7-12 tahun yang akan dilakukan prosedur pemasangan infus di Rumah Sakit Islam Sultan Agung Semrang Unit Gawat Darurat Semarang.

Teknik sampling pada penelitian ini menggunakan teknik nonprobability sampling dengan pendekatan consecutive sampling, yaitu dengan memilih subjek yang memenuhi kriteria penelitian dan dimasukkan dalam penelitian sampai kurun waktu tertentu, sampai jumlah klien yang diperlukan terpenuhi (Dahlan, 2009). jumlah ini sesuai dengan kriteria penelitian eksperimen menurut Dempsey(2002).

Sampel yang digunakan dalam penelitian harus memenuhi kriteria inklusi dan eksklusi. Kriteria inklusi dari penelitian ini yaitu: (I) Anak usia 7-12 tahun; (2)Orang tua setuju anaknya menjadi responden, yang dibuktikan dengan surat persetujuan menjadi responden; (3) Anak yang akan menjalani prosedur pemasangan infus; (4) Anak dalam keadaan sadar penuh. Sedangkan kriteria eksklusinya adalah: Kriteria eksklusi pemberian ethyl chloride: (I) Anak alergi terhadap krim ethyl chloride; (2) Tiba-tiba anak menolak sebelum prosedur selesai. Kriteria eksklusi guided imagery: (I) Tiba-tiba anak menolak sebelum prosedur selesai; (2) Anak tuli atau tidak dapat mendengar dengan baik; (3) Anak menolak menggunakan earphone. Berdasarkan kriteria tersebut, sampel yang digunakan dalam penelitian ini berjumlah 30 responden (masing-masing kelompok 15 responden), jumlah ini sesuai dengan kriteria penelitian eksperimen menurut Dempsey (2002) bahwa sebuah penelitian intervensi jumlah minimal responden 15.

\section{HASIL}

Hasil Penelitian terkait perbedaan respon nyeri pada anak usia 7- 12 tahun saat pemasangan infus setelah diberikan intervensi ethyl chloride dan guided imagery dilakukan selama bulan maret sampai juli 2017 akan dijelaskan dalam tabel-tabel berikut.

Hasil penelitian terkait karakteristik responden meliputi usia, jenis kelamin, pengalaman diinfus sebelumnya serta respon nyeri pada masing-masing kelompok intervensi. Karakteristik responden berdasarkan usia akan dijelaskan pada tabel I adapun karakteristik responden berdasarkan jenis kelamin dan pengalaman diinfus sebelumnya akan disajikan dalam tabel 2.

Tabel 1. Distribusi Responden Berdasarkan Usia pada Bulan Maret - Juli 2017 (n:30)

\section{Median (Minimum-Maksimum)}

Usia 9(7-12)

Data pada tabel I menjelaskan bahwa nilai tengah dari distribusi responden berdasarkan usia adalah 9 tahun.

Tabel 2. Distribusi Responden Berdasarkan Jenis

Kelamin Dan Pengalaman Diinfus Sebelumnya pada Bulan Maret - Juli 2017 (n:30)

\begin{tabular}{llcc}
\hline & & $\mathbf{n}(\%)$ & IK 95\% \\
\hline Jenis Kelamin & Laki-laki & I7 (56.7) \\
& Perempuan & I3 (43.3) \\
\hline Pengala ma n & Pernah & $2(6,7)$ \\
Sebelumnya & Tidak Pernah & $28(93,3)$ \\
\hline \multicolumn{1}{c}{ Total } & & $30(100)$ \\
\hline
\end{tabular}




\section{NURSING PRACTICES}

Data pada tabel 2 menjelaskan bahwa responden terbanyak berjenis kelamin laki-laki yaitu sebanyak 17 responden (56,7\%), adapun terkait pengalaman diinfus sebelumnya terbanyak adalah responden yang tidak pernah diinfus yaitu 28 responden (93,3\%).

Analisis bivariat digunakan untuk membandingkan antara dua variabel untuk membuktikan hipotesis penelitian. Analisis bivariat pada penelitian ini yaitu untuk membandingkan antara ethyl chloride dan guided imagery terhadap respon nyeri pada anak. Uji analisis yang digunakan adalah uji Mann Whitney. Adapun hasil analisis bivariat akan dijelaskan pada tabel 3:

Tabel 3. Distribusi Perbandingan Tingkat Nyeri Antara Kelompok Intervensi Ethyl Chloride Dengan Kelompok Intervensi Guided Imagery pada Bulan Maret sampai Juli $2017(\mathrm{n}=30)$

\begin{tabular}{cccc}
\hline Intervensi & $\mathbf{N}$ & $\begin{array}{c}\text { Median } \\
\text { (minimum-maksimum) }\end{array}$ & $\begin{array}{c}\text { Nilai } \\
\boldsymbol{\rho}\end{array}$ \\
\hline Ethyl Chloride & 15 & $2(1-4)$ & 0,530 \\
\cline { 1 - 3 } Guided Imagery & 15 & $3(2-3)$ & \\
\hline
\end{tabular}

Tabel 3. merupakan tabel hasil uji Mann-Whitney dengan hasil median tingkat nyeri responden pada kelompok ethyl chloride pada skala 2 dengan rentang antara skala I sampai 4 , sedangkan pada kelompok guided imagery pada skala 3 dengan rentang antara skala 2 sampai 3, hal ini dapat diartikan bahwa pada kelompok guided imagery berada pada skala 3 kebawah sedangkan pada kelompok ethyl chloride berada pada skala 3 keatas. Dimana skala I adalah "nyeri sedikit", skala 2 adalah "sedikit lebih nyeri", skala 3 adalah "lebih nyeri lagi", skala 4 adalah "nyeri sekali". Nilai signifikasinya sebesar 0,530 ( $\square>0,05)$, artinya hipotesis pada penelitian ini ditolak, dimana hasil tersebut dapat disimpulkan bahwa tidak terdapat perbedaan yang bermakna antara ethyl chloride dan guided imagery terhadap respon nyeri saat pemasangan infus pada anak.

\section{PEMBAHASAN}

Intervensiethyl chloride efektif digunakan untukmengurangi nyeri pada anak saat dilakukan pemasangan infus. Hal tersebut terbukti dari data respon nyeri yang menunjukkan tidak ada responden yang mengalami nyeri hebat saat diberikan ethyl chloride. Hasil ini didukung oleh penelitian yang dilakukan oleh
Novianti, Novayelinda, dan Utomo (20 I2) tentang pengaruh pemberian anestesi lokal terhadap penurunan nyeri pada anak prasekolah yang dilakukan prosedur pengambilan darah vena. Hasil penelitian menunjukkan bahwa pemberian anestesi lokal pada area pengambilan darah vena dapat menurunkan atau menghilangkan tingkat nyeri.

Anestesi lokal adalah keadaan dimana sebagian tubuh tertentu (lokalisasi) mengalami kehilangan sensasi. Anestesi lokal dapat dioleskan atau diinjeksikan di bagian kulit atau tubuh tertentu (Potter \& Perry, 2006). Kerja dari anestesi lokal ini adalah dengan memblokir syaraf, yaitu pada fungsi motorik, sensorik, dan saraf otonom. Anestesi lokal lebih kecil risikonya dari pada anestesi umum. Jenis anestesi lokal ethyl chloride dapat menyebabkan pendinginan pada kulit, sehingga dapat mengganggu kemampuan tubuh untuk merasakan sakit (Siregar, 2007). Oleh karena itu ethyl chloride, efektif digunakan untuk mengurangi nyeri saat pemasangan infus.

Intervensi guided imagery efektif digunakan untuk mengurangi nyeri pada anak saat pemasangan infus. Data respon nyeri responden yang diberikan guided imagery menunjukkan respon nyeri tertinggi berada pada skala 3. Hasil ini didukung oleh penelitian yang dilakukan oleh Apóstolo dan Kolcaba (2009), mengenai pengaruh guided imagery terhadap kenyamanan, depresi, kecemasan, dan stres pada pasien dengan gangguan depresif, mendapatkan hasil bahwa guided imagery adalah salah satu metode yang efektif dalam meningkatkan kenyamanan anak, selain itu metode ini relatif mudah untuk dipelajari dan digunakan oleh anak.

Guided Imagery adalah salah satu metode pengontrolan nyeri yang termasuk kedalam teknik perilaku kognitif (cognitive-behavioral), tujuan dari teknik ini yaitu untuk memberikan kenyamanan, mengubah respon psikologi untuk mengurangi persepsi nyeri dan mengoptimalisasi fungsi tubuh (Kozier \& Erb's, 20।2). Penelitian oleh van der Veek, Derkx, Benninga, Boer, dan de Haan, (2013)posttreatment, and at 6- And 12-month follow-up. Primary outcomes were level of abdominal pain (AP, mendapatkan hasil bahwa cognitive behavior therapy (CBT) efektif dalam menurunkan nyeri pada anak-anak dengan nyeri fungsi abdomen (Functional Abdominal Pain).

Guided imagery merupakan salah satu teknik yang berpengaruh terhadap perilaku kognitif anak. Dimana tingkat kognitif anak tergantung pada tingkatan usia anak tersebut. 
Oleh karena itu pada guided imagery akan semakin efektif digunakan pada anak yang lebih besar dengan kecenderungan tingkat kognitif lebih tinggi. Hal ini didukung oleh teori perkembangan menurut Piaget yang menjelaskan mengenai tahap perkembangan kognitif pada anak usia 7-II tahun, yaitu pada tahap 'Konkret Operasional', dengan ciri-ciri anak memiliki kemampuan dalam memahami aturan dan percakapan sehingga menghasilkan suatu pemikiran yang logis dan mental operasional, misal seperti pemusatan, pembagian transformasi, klasifikasi dari dua atribut atau lebih, serta alasan deduktif dan induktif (Potter \& Perry, 2006).

Hasil analisis bivariat menunjukkan tidak ada perbedaan antara kelompok ethyl chloride dan guided imagery terhadap respon nyeri anak saat pemasangan infus. Artinya intervensi guided imagery dapat dilakukan pada lingkup perawatan gawat darurat dan cukup efektif untuk mencegah trauma pada anak saat pemasangan infus. Hasil yang diperoleh diharapkan dapat membantu pelayanan keperawatan agar bisa memilih metode yang tepat untuk mengatasi nyeri pada anak saat dilakukan tindakan infus. Salah satu tujuanya adalah untuk mengurangi trauma pada anak, saat dilakukan tindakan invasif pertama diharapkan anak akan lebih kooperatif untuk dilakukan tindakan invasif berikutnya.

Pada penelitian ini didapatkan hasil bahwa penggunaan guided imagery lebih efektif dibanding penggunaan ethyl chloride. Hal ini terlihat dari respon nyeri yang didapatkan pada penggunaan ethyl chloride terdapat satu responden yang mengalami nyeri dengan skala 4 sedangkan pada penggunaan guided imagery respon nyeri tertinggi berada pada skala 3. Hal ini dapat terjadi karena usia responden yang masuk kelompok guided imagery paling banyak pada usia 9 tahun ke atas. Sesuai penjelasan sebelumnya yang menyebutkan bahwa intervensi guided imagery akan efektif jika diberikan pada anak yang lebih besar karena tingkat kognitifnya cenderung lebih tinggi. Pada saat guided imagery diberikan terjadi proses mudulasi dalam tubuh, melalui sistem analgesik endogen yang melibatkan pengeluaran endorfin dalam tubuh oleh sistem syaraf sehingga dapat mengurangi nyeri. Edorfin memiliki efek relaksasi pada tubuh dengan menghambat transmisi subtansi zat kimia yang dikeluarkan dari jaringan yang terluka.

Penggunaan ethyl chloride dapat digunakan di Rumah sakit, karena metode ini cukup efektif, dan dapat mempermudah serta mempercepat perawat untuk melakukan pemasangan infus pada anak. Sedangkan penggunaan guided imagery juga bisa digunakan untuk pilihan alternatif, karena lebih terjangkau dan anak serta orang tua lebih banyak memilih metode ini karena lebih aman tanpa bahan kimia, dan anak cenderung lebih tenang.

Penelitian ini juga dapat menambah pengetahuan di dunia pendidikan, sehingga dapat menambah wawasan terutama metode penanganan nyeri yang tepat dilakukan pada anak usia 7- 12 tahun. Selain itu penelitian ini juga dapat menjadi rujukan untuk dilakukan penelitian selanjutnya, terutama yang terkait dengan menejemen nyeri pada anak.

Keterbatasan penelitian ini yaitu jumlah sampel yang terbatas dan sampel datang ke rumah sakit tidak bersamaan sehingga membutuhkan waktu yang lama dalam pengumpulan data.

\section{KESIMPULAN}

Hasil penelitian menunjukkan tidak ada perbedaan skor nyeri yang bermakna antara ethyl chloride dan guided imagery, sehingga guided imagery dapat dijadikan salah satu metode untuk mengurangi nyeri karena lebih mudah dan dari segi biaya lebih murah. Bagi rumah sakit hal tersebut dapat dijadikan kebijakan untuk mengurangi trauma pada anak saat diinfus dan meminimalkan dampak negatif lainnya. Penelitian ini dapat dijadikan dasar untuk penelitian selanjutnya, misalnya dengan menambah jumlah responden, serta melakukannya pada usia yang berbeda dengan teknik yang berbeda.

\section{UCAPAN TERIMA KASIH}

Ucapan terima kasih kami sampaikan kepada DRPM Diten Penguatan Risbang yang telah mendanai riset ini sehingga bisa terlaksana dengan lancar, Iwan Ardian, SKM., M.Kep selaku Dekan FIK Unissula yang telah memberikan ijin dan supportnya untuk dapat melakukan penelitian dengan baik dan RSISA yang memberikan kesempetan penulis untuk melakukan penelitian di rumah sakit tersebut.

\section{REFERENSI}

Andarmoyo, S. (2013). Konsep dan proses keperawatan nyeri. Jogjakarta: Arruz Media.

Apóstolo, J. L. A., \& Kolcaba, K. (2009). The effects of guided imagery on comfort, depression, anxiety, and stress of psychiatric inpatients with depressive 


\section{NURSING \\ PRACTICES}

disorders. Archives of Psychiatric Nursing, 23(6), 403-411. doi:10.1016/j.apnu.2008.12.003

Creswell, J. W. (2010). Research design: Pendekatan kualitatif, kuantitatif, dan mixed. Jogjakarta: Pustaka Pelajar.

Dahlan, M. S. (2009). Besar sampel dan cara pengambilan sampel dalam penelitian kedokteran dan kesehatan. Jakarta: Salemba Medika.

Glasper, A. \& Richardson, J. (2006). A textbook of children's and young people's nursing. Philadelpia: Elsevier

Hockenberry, M. J., \& Wilson, D. (2009). Wong's essentials of pediatric nursing (8th ed.). St. Louis Missouri: Mosby Elsvier.

Ismanto, A. Y. (2011). Studi komparatif pemberian ASI dan topikal anestesi terhadap respon nyeri imunisasi pada bayi di Puskesmas Bahu Manado. Universitas Indonesia. Retrieved from http://lontar.ui.ac.id/opac/ themes/libri2/detail.jsp?id=20280168\&lokasi=lokal

Kozier, \& Erb's. (2012). Fundamentals of nursing. America: Person PLC.

Mariyam, \& Widodo, S. (2012). Pengaruh guided imagery terhadap tingkat nyeri pada anak usia 7-13 tahun saat dilakukan pemasangan infus di RSUD Kota Semarang. In Seminar Hasil-Hasil Penelitian (p. 978 (6), 6). Semarang: LPPM UNIMUS.

Novianti, Novayelinda, R., \& Utomo, W. (2012). Pengaruh pemberian eutetic mixture of local anestetic terhadap penurunan nyeri pada anak prasekolah yang dilakukan pengambilan darah vena. Universitas Riau. Retrieved from http://repository.unri.ac.id/ bitstream/123456789/1889/1/MANUSCRIPT.pdf.

Potter, A. P., \& Perry, G. P. (2006). Buku Ajar Fundamental keperawatan. Jakarta: EGC.

Siregar, I. A. (2007). Perbandingan efektifitas anestesi oles dengan anestesi semprot dalam menurunkan intensitas nyeri pada pungsi arteri. Universitas Sumatera Utara. Retrieved from http://repository.usu.ac.id/ bitstream/123456789/6263/1/Ira Aliza1.pdf

Van Der Veek, S. M. C., Derkx, B. H. F., Benninga, M. A., Boer, F., \& de Haan, E. (2013). Cognitive behavior therapy for pediatric functional abdominal pain: A randomized controlled trial. Pediatrics, 132(5), e1163e1172. doi: 10.1542/peds.2013-0242 